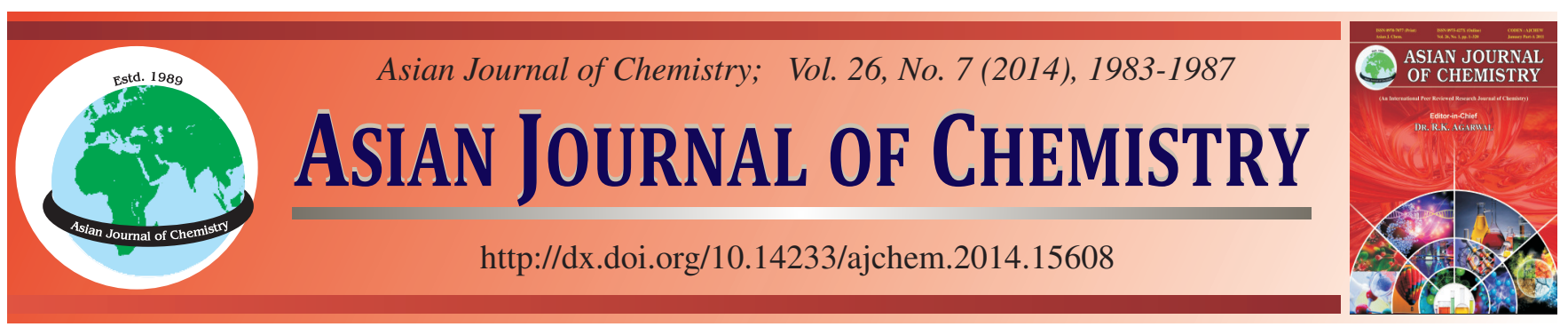

\title{
Chemical and Isotopic Characteristics of Groundwater from Deep Sandstone Aquifer in Northern Anhui Province, China: A Case Study
}

\author{
L.H. SuN ${ }^{*}$ and H.R. GuI
}

School of Earth Science and Engineering, Suzhou University, Suzhou, P.R. China

*Corresponding author: Fax: +86 557 3685692; Tel: +86 557 2871038, E-mail: sunlinh@126.com

\begin{abstract}
For evaluating the hydro-chemical and isotopic contents of groundwater, eight samples from the a deep sandstone aquifer in Qianyingzi coal mine, northern Anhui Province, China have been collected for analyzing major ion concentrations and stable isotopic (hydrogen and oxygen) contents. Two water types were recognized: $\mathrm{Na}-\mathrm{HCO}_{3}$ and $\mathrm{Na}-\mathrm{SO}_{4}$. In comparison with the drinking water standards of World Health Organization, only $\mathrm{Ca}^{2+}, \mathrm{Mg}^{2+}$ and $\mathrm{Cl}^{-}$concentrations can meet the demand. Correlations between ions imply that chemical compositions of the groundwater was controlled by multi processes i.e. dissolution of evaporate, weathering of silicate minerals and cation exchange. The stable isotopic contents of the groundwater samples from the sandstone aquifer is similar to the shallow groundwater and limited in a narrow range, indicating that the aquifer is independent relative to other aquifers and, the groundwater in the aquifer was recharged by paleo-precipitation, which was modified by the processes during penetration from surface to the aquifer or the water rock interaction during the long residence time in the aquifer, rather than the sealed up water during sedimentation.
\end{abstract}

Keywords: Hydro-geochemistry, Water rock interaction, Groundwater, Deep seated environment.

\section{INTRODUCTION}

Groundwater, especially deep groundwater has dual natures: firstly, it is important for living beings, especially to the mankind and is essential for life. Therefore, with rapid development of economics, the demand of groundwater has increased significantly and most of them are extracted from deep environment because some of the shallow groundwater has been polluted ${ }^{1,2}$. Simultaneously, groundwater is a potential threat for deep coal exploration because it is the main source of inrush water, which has brought to persons with great loss ${ }^{3}$. More than 8,000 people died and the economic losses was higher than 30 billion yuan in China during the last two decades because of water inrush.

Therefore, the study of chemical composition of groundwater is important for either groundwater usage or safety of coal mining because: (1) the quality and application of groundwater based on mostly the chemical composition ${ }^{4-6}$ and (2) prevention and governance of water inrush needs to know the chemical composition of groundwater as it can be used for water source identification ${ }^{7,8}$.

Previous studies ${ }^{9,10}$ revealed that chemical composition of groundwater evolves from its primary composition (i.e. precipitation) due to constant interaction with the ambient environment before and after recharge: e.g. interactions with surface water, anthropogenic inputs and wall rocks or soils, as well as mixing with different types of groundwater. The chemical study of groundwater focused mainly on the chemical composition of the groundwater, as well as its controlling factors and the applied chemical components include major ions, trace elements (including rare earth elements) and stable isotopes $^{11-13}$.

Groundwater is a main source for drinking and irrigation in northern Anhui Province, China and, therefore, exploitation and utilization of groundwater is important for the local economic development ${ }^{14}$. Moreover, the area is one of China's major coal producing regions and so, the safety of coal mining (i.e. water inrush controlling) is also important for the steady development of the regional economy ${ }^{3}$.

In this paper, groundwater samples from a sandstone aquifer in Qianyingzi coal mine, northern Anhui Province, China, which is considered to be the most direct threat to coal mining, have been collected and analyzed for major ion concentrations and stable isotopic compositions (hydrogen and oxygen). The objective of the study include: (1) evaluating the chemical and isotopic compositions of the groundwater and (2) identifying the processes controlling them. Moreover, because the Qianyingzi coal mine is new mine, the study therein will provide information for the future water hazard controlling. 


\section{EXPERIMENTAL}

Hydrological condition of study area: Qianyingzi coal mine is located $15 \mathrm{~km}$ south to Suzhou City, northern Anhui Province, China (Fig. 1), the length of mine is $8.3 \mathrm{~km}$ from south to north and the width is $6 \mathrm{~km}$ from east to west, the total area is $74 \mathrm{~km}^{2}$. The longitude and latitude of the coal mine are E $116^{\circ} 51^{\prime} 00^{\prime \prime}-117^{\circ} 00^{\prime} 00^{\prime \prime}$ and N 33 $27^{\circ} 00^{\prime \prime}-33^{\circ} 32^{\prime} 30^{\prime \prime}$, respectively. As one of the tributaries of the Huaihe river, Hui river flows through the coal mine in the southwestern part with annual average water level between 17.2 and $16.1 \mathrm{~m}$. Moreover, there are many artificial channels in the area and the water network is relatively dense. The climate of the area belongs to monsoon, warm temperate and semi-humid climate with an annual average temperature of $14-15^{\circ} \mathrm{C}$. The average annual rainfall is $850 \mathrm{~mm}$ and most of them are concentrated between July and August.

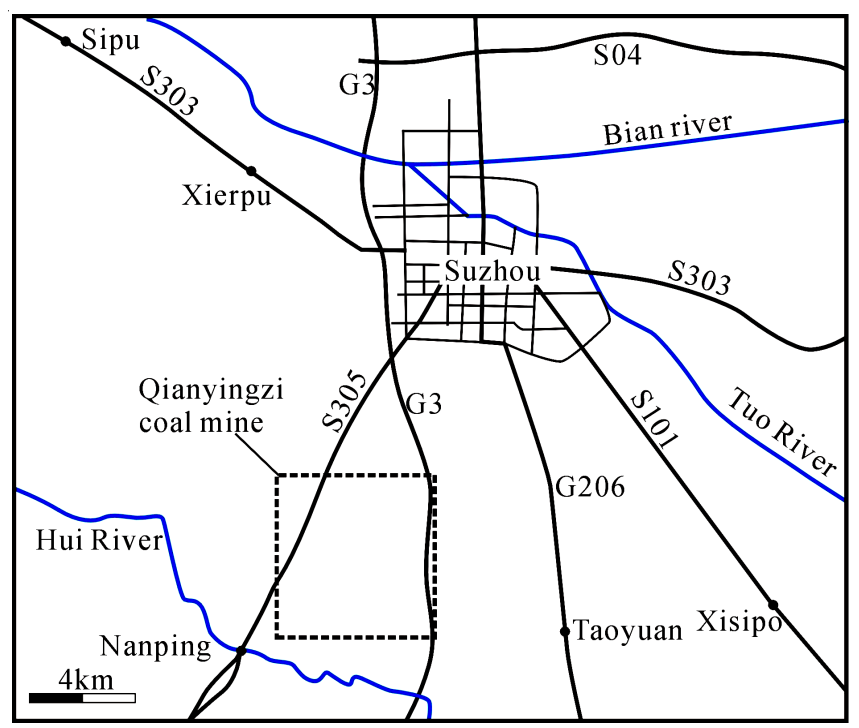

Fig. 1. Location of the study coal mine

Early Paleozoic to Cenozoic strata have been uncovered by drilling cores, they include Ordovician limestone with thickness higher than $21 \mathrm{~m}$, Carboniferous limestone and mudstone (140-190 m), Permian sandstone, siltstone, mudstone and coal seams $(1267 \mathrm{~m})$, Tertiary purple-red sand and conglomerate $(360 \mathrm{~m})$ and Quaternary grey-yellow sand, silt and clay (49$87 \mathrm{~m})$.

Previous investigations revealed that the aquifers in the mine are divided into three aquifers from up to down: loose layer aquifer, coal bearing sandstone aquifer and the underlying limestone aquifer. The loose layer aquifer is subdivided into two aquifers, the tertiary and quaternary aquifer, the thickness of them are 36 and $7 \mathrm{~m}$, respectively and they enriched in water. The coal bearing aquifer is subdivided into three aquifers: the fifth, sixth and seventh aquifers, the thickness of which are 11, 21 and $52 \mathrm{~m}$, respectively and the water amount is limited as revealed by drilling activities. The thickness of the limestone aquifer is $35 \mathrm{~m}$ in average with large amount of cracks in limestone and the water abundances are heterogeneous.

The study focused on only the groundwater from coal bearing aquifer, a sandstone dominant aquifer in Qianyingzi coal mine, northern Anhui Province, China. Because the coal mine is a new mining one, it is difficult for sample collection and therefore, only eight samples had been collected in the alley.

Water $\mathrm{pH}$ and total dissolved solids (TDS) were measured in the field with a portable $\mathrm{pH}$ and TDS meter. Water samples were filtered through $0.45 \mu \mathrm{m}$ pore-size membrane and collected into two $2.0 \mathrm{~L}$ polyethylene bottles that had been cleaned in the laboratory. Then the samples had been sending to the laboratory for analysis of major ions.

Major ion analytical processes were taken place in the Engineering and Technology Research Center of Coal Exploration in Anhui Province, China following the methods bellow: $\mathrm{Na}^{+}$was analyzed by Atomic Absorption Spectrometry, $\mathrm{SO}_{4}{ }^{2-}$ and $\mathrm{Cl}^{-}$were analyzed by Ion Chromatography, $\mathrm{Ca}^{2+}$ and $\mathrm{Mg}^{2+}$ were analyzed by EDTA Titration and alkaline (including $\mathrm{HCO}_{3}{ }^{-}$and $\mathrm{CO}_{3}{ }^{2-}$ ) was analyzed by acid-base titration.

Stable isotopic compositions (including hydrogen $(\delta \mathrm{D})$ and oxygen $\left(\delta^{18} \mathrm{O}\right)$ ) were analyzed in the State Key Laboratory of Geological Processes and Mineral Resources, China University of Geosciences (Wuhan). $\mathrm{CO}_{2}-\mathrm{H}_{2} \mathrm{O}$ equilibrium method was introduced to process the $\delta^{18} \mathrm{O}$ analysis and uranium reduction process method was introduced for $\delta \mathrm{D}$ analysis. All samples were analyzed by mass spectrometry.

\section{RESULTS AND DISCUSSION}

Hydro-chemical composition of groundwater: The analytical results of major ion concentrations of groundwater from the sandstone aquifer in Qianyingzi coal mine are given in Table-1. For comparison, the major ion concentrations are also shown in Fig. 2 in comparison with the drinking water standard of world health organization ${ }^{15}$.

The $\mathrm{pH}$ value in groundwater ranges from 8.0 to 8.9 with an average value of 8.4 , indicating an alkaline nature. In comparison with $\mathrm{WHO}^{15}$, only three samples can meet the

\begin{tabular}{|c|c|c|c|c|c|c|c|c|c|c|c|}
\hline \multicolumn{12}{|c|}{$\begin{array}{r}\text { TABLE-1 } \\
\text { MAJOR ION CONCENTRATIONS }(\mathrm{mg} / \mathrm{l}), \delta \mathrm{D} \text { ANI }\end{array}$} \\
\hline ID & $\mathrm{pH}$ & $\mathrm{Na}^{+}$ & $\mathrm{Ca}^{2+}$ & $\mathrm{Mg}^{2+}$ & $\mathrm{Cl}^{-}$ & $\mathrm{SO}_{4}{ }^{2-}$ & $\mathrm{HCO}_{3}^{-}$ & $\mathrm{CO}_{3}^{2-}$ & TDS & $\delta \mathrm{D}$ & $\delta^{18} \mathrm{O}$ \\
\hline QYZ-1 & 8.5 & 652 & 4.75 & 3.84 & 182 & 376 & 739 & 116 & 1703 & -58.5 & -8.58 \\
\hline QYZ-2 & 8.9 & 582 & 3.17 & 3.36 & 282 & 4.53 & 817 & 129 & 1414 & -64.8 & -8.59 \\
\hline QYZ-3 & 8.1 & 1178 & 24.5 & 4.80 & 199 & 1688 & 736 & 0 & 3463 & -68.5 & -8.59 \\
\hline QYZ-4 & 8.6 & 1718 & 26.1 & 11.5 & 150 & 2838 & 688 & 70.4 & 5158 & -64.8 & -8.58 \\
\hline QYZ-5 & 8.3 & 544 & 6.33 & 3.84 & 189 & 125 & 854 & 70.4 & 1365 & -64.0 & -8.36 \\
\hline QYZ-6 & 8.7 & 472 & 5.54 & 3.84 & 146 & 21.4 & 861 & 72.7 & 1152 & -67.8 & -8.75 \\
\hline QYZ-7 & 8.0 & 524 & 16.6 & 19.2 & 407 & 8.64 & 817 & 0 & 1385 & -64.2 & -8.70 \\
\hline QYZ-8 & 8.4 & 950 & 102 & 87.4 & 288 & 1900 & 291 & 34.1 & 3506 & -66.9 & -8.78 \\
\hline
\end{tabular}


demand ( $\mathrm{pH}=6.5-8.5$ ) for drinking. TDS concentrations of the groundwater range from 1152 to $5158 \mathrm{mg} / \mathrm{L}$ with an average value of $2393 \mathrm{mg} / \mathrm{L}$, much higher than those of fresh water $(1000 \mathrm{mg} / \mathrm{L})^{15}$. Moreover, as can be seen from Fig. 2, among all of the anions and cations, only $\mathrm{Ca}^{2+}, \mathrm{Mg}^{2+}$ and $\mathrm{Cl}^{-}$ concentrations are lower than the WHO permissible values ${ }^{15}$.

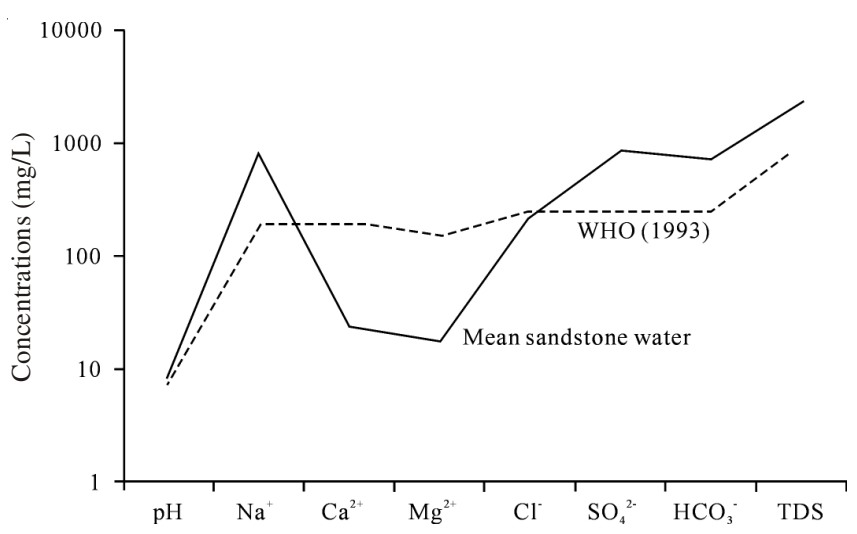

Fig. 2. Mean major ion concentration of groundwater in comparison with WHO [Ref.15]

As to the cations, the concentrations of $\mathrm{Na}^{+}, \mathrm{Ca}^{2+}$ and $\mathrm{Mg}^{2+}$ ions ranged from 472 to $1718,3.17$ to 200 and 3.36 to 150 with mean of $828,23.7$ and $17.2 \mathrm{mg} / \mathrm{L}$, respectively. Their concentrations (meq/L) represent on average $93.3 \%, 3.1 \%$ and $3.7 \%$ of all the cations, respectively. Among the anions, the concentrations of $\mathrm{Cl}^{-}, \mathrm{SO}_{4}{ }^{2-}$ and $\mathrm{HCO}_{3}{ }^{-}$ions lie in between 146 and 407, 4.53 and 2838, 291 and $861 \mathrm{mg} / \mathrm{L}$, their mean concentrations are 230,870 and $725 \mathrm{mg} / \mathrm{L}$, respectively. The order of their abundance $(\mathrm{meq} / \mathrm{L})$ is $\mathrm{SO}_{4}{ }^{2-}>\mathrm{HCO}_{3}{ }^{-}>\mathrm{Cl}^{-}$, contributing on average, $47.0 \%, 30.8 \%$ and $16.9 \%$ to the total anions, respectively. Based on Piper and Durov diagrams (Fig. 3), the groundwater samples in this study can be subdivided into two types: $\mathrm{Na}-\mathrm{HCO}_{3}$ and $\mathrm{Na}-\mathrm{SO}_{4}$.

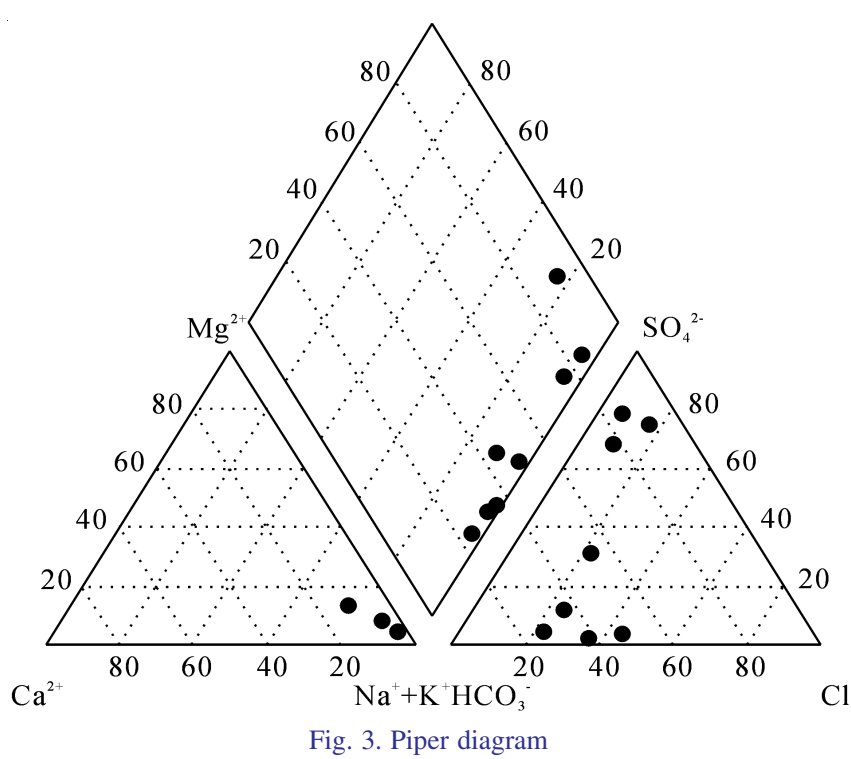

Factor controlling groundwater chemistry: The controls on the hydrochemistry of groundwater largely depend on the chemistry of recharging water, water-aquifer interaction, or both, as well as groundwater residence time within the aquifer, which represent the degree of water-rock interaction. Three general processes contribute to the generation of solutes in groundwater: evaporation dissolution, carbonate dissolution and silicate weathering ${ }^{16}$.

As can be seen from Fig. 4, the groundwater samples in this study have $\mathrm{Ca}^{2+} / \mathrm{Na}^{+}$and $\mathrm{Mg}^{2+} / \mathrm{Na}^{+}$ratios range from 0.006 to 0.123 and 0.008 to 0.174 , respectively and suggest that dissolution of evaporate and weathering of silicate minerals dominant in the sandstone aquifer ${ }^{17}$. It is also supported by the correlation between $\mathrm{Na}^{+}-\mathrm{Cl}^{-}$and $\left(\mathrm{HCO}_{3}{ }^{-}+\mathrm{SO}_{4}{ }^{2-}\right)-\left(\mathrm{Ca}^{2+}+\right.$ $\mathrm{Mg}^{2+}$ ) (Fig. 5) that all of the samples have higher $\mathrm{Na}^{+}$and $\left(\mathrm{HCO}_{3}{ }^{-}+\mathrm{SO}_{4}{ }^{2-}\right)$ concentrations relative to $\mathrm{Cl}^{-}$and $\left(\mathrm{Ca}^{2+}+\mathrm{Mg}^{2+}\right)$, respectively ${ }^{18}$.
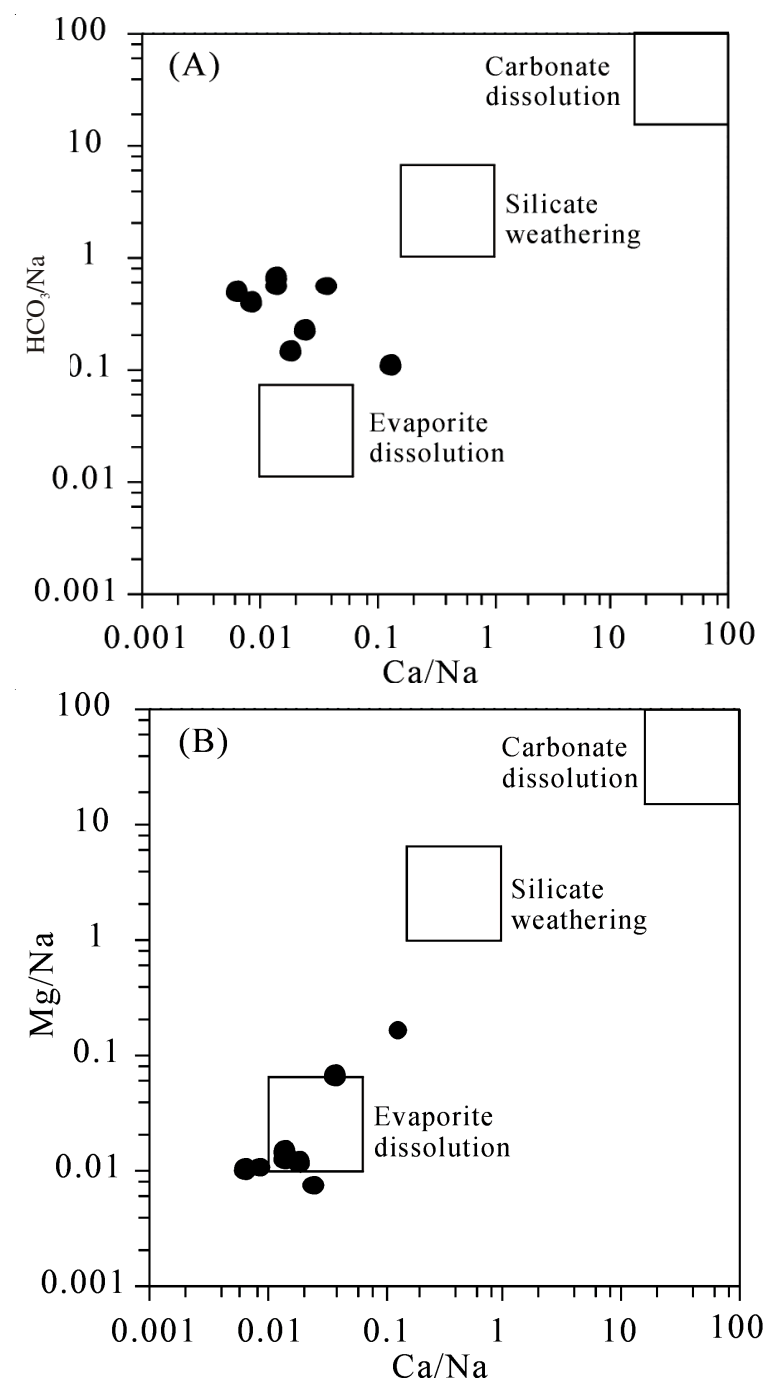

Fig. 4. $\mathrm{Na}^{+}$normalized $\mathrm{Ca}^{2+}-\mathrm{HCO}_{3}{ }^{-}$(A) and $\mathrm{Ca}^{2+}-\mathrm{Mg}^{2+}$ (B) plots

The $\left(\mathrm{Ca}^{2+}+\mathrm{Mg}^{2+}\right) / \mathrm{HCO}_{3}{ }^{-}$ratios of all groundwater samples except for one (QYZ-8) in this study range from 0.03 to 0.20 with mean $=0.10$ (Fig. 6A), which suggests that an extra source of $\mathrm{HCO}_{3}{ }^{-}$balanced by $\mathrm{Na}^{+}$, supports the weathering of silicate minerals ${ }^{19}$. Additionally, the low $\left(\mathrm{Ca}^{2+}+\mathrm{Mg}^{2+}\right) / \mathrm{HCO}_{3}{ }^{-}$ratios $(<0.5)$ of most of the groundwater samples could be the result of $\left(\mathrm{Ca}^{2+}+\mathrm{Mg}^{2+}\right)$ depletion by cation exchange.

Because $\mathrm{Cl}^{-}, \mathrm{SO}_{4}{ }^{2-}$ and $\mathrm{HCO}_{3}{ }^{-}$record dissolution of halite, gypsum and carbonate minerals (calcite and/or dolomite), the $\left(\mathrm{Na}^{+}-\mathrm{Cl}^{-}\right)$represented the $\mathrm{Na}^{+}$gained or lost relative to that 

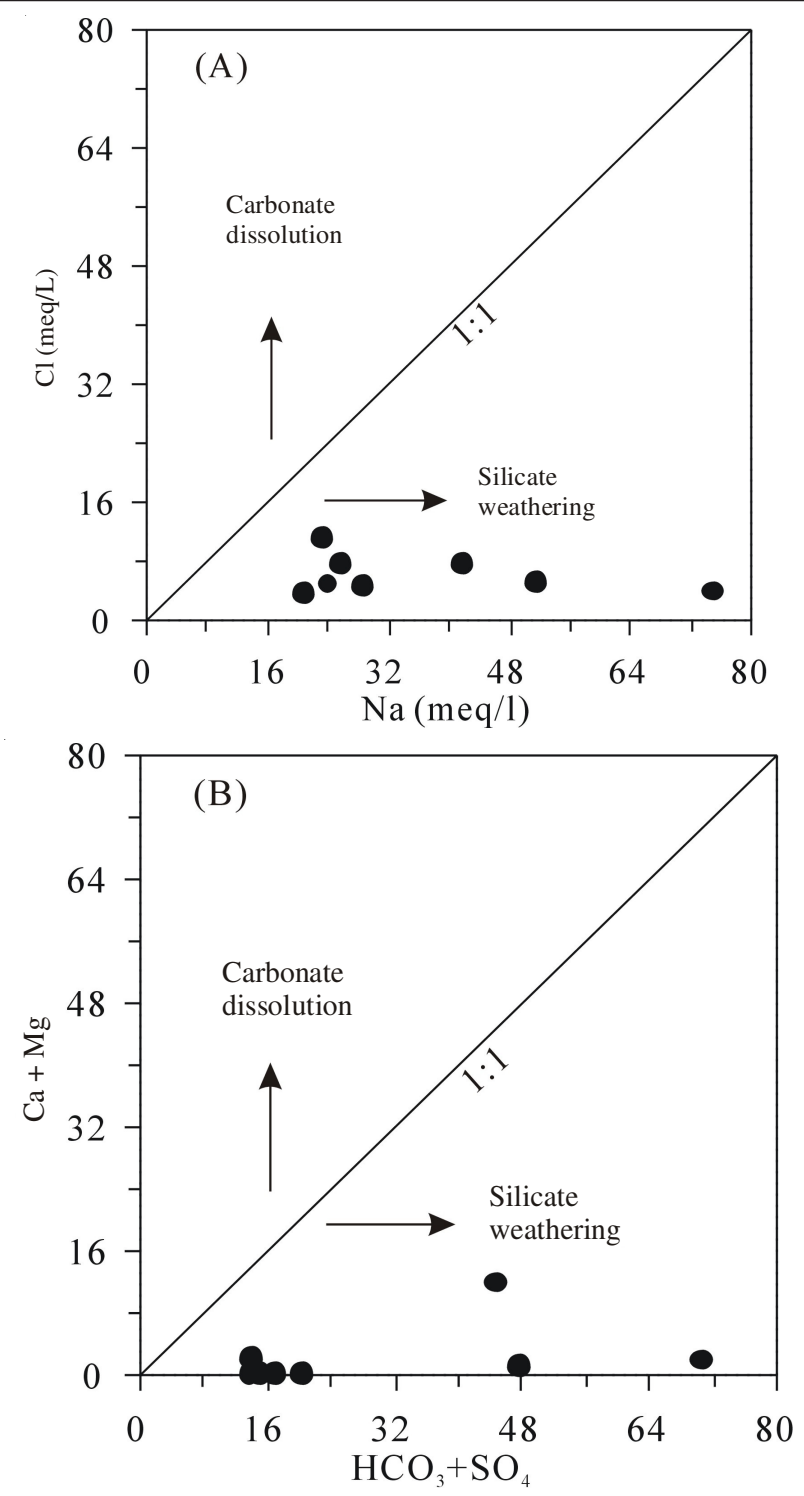

Fig. 5. $\mathrm{Na}^{+}-\mathrm{Cl}^{-}$and $\left(\mathrm{HCO}_{3}{ }^{-}+\mathrm{SO}_{4}{ }^{2-}\right)-\left(\mathrm{Ca}^{2+}+\mathrm{Mg}^{2+}\right)$ diagrams

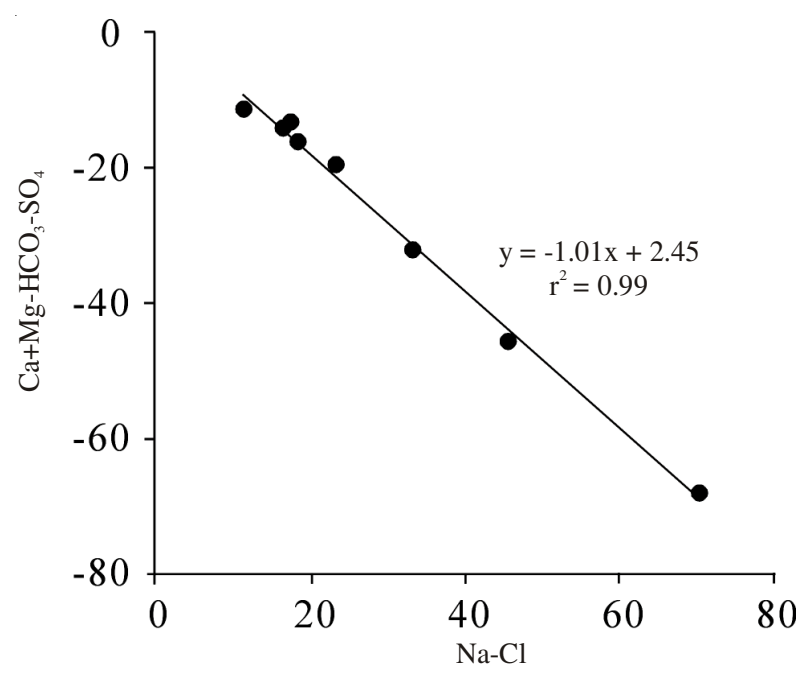

Fig. 6. Correlation between $\left(\mathrm{Na}^{+}-\mathrm{Cl}^{-}\right)$and $\left(\mathrm{Ca}^{2+}+\mathrm{Mg}^{2+}-\mathrm{SO}_{4}{ }^{2-}-\mathrm{HCO}_{3}{ }^{-}\right)$

provided by halite dissolution, whereas the $\left(\mathrm{Ca}^{2+}+\mathrm{Mg}^{2+}-\mathrm{SO}_{4}{ }^{2-}\right.$ $\left.-\mathrm{HCO}_{3}{ }^{-}\right)$represented the $\mathrm{Ca}^{2+}$ and $\mathrm{Mg}^{2+}$ gained or lost relative to that provided by calcite, dolomite and gypsum dissolution. Based on this consideration, cation exchange between $\mathrm{Na}^{+}$and $\mathrm{Ca}^{2+}$ and/or $\mathrm{Mg}^{2+}$ was constrained by the good correlation between $\left(\mathrm{Na}^{+}-\mathrm{Cl}^{-}\right)$and $\left(\mathrm{Ca}^{2+}+\mathrm{Mg}^{2+}-\mathrm{SO}_{4}{ }^{2-}-\mathrm{HCO}_{3}{ }^{-}\right)$in Fig. 7.

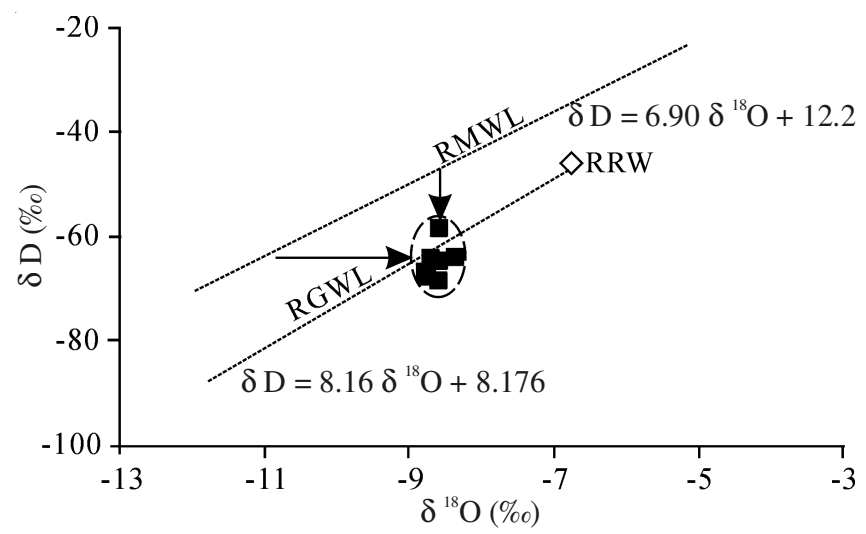

Fig. 7. Stable isotope variations

Isotopic composition of groundwater: Stable isotopes of groundwater are influenced by processes affecting the groundwater rather than the solutes. Thus, they can help to identify groundwater that have undergone evaporation or mixing with waters from other aquifers. Moreover, they can provide reliable information about the mode and origin of groundwater recharge. These processes can be point out mainly through the plot of groundwater samples in $\delta \mathrm{D}-\delta^{18} \mathrm{O}$ diagram with respect to the global meteoric water line (GMWL $)^{20}$, regional meteoric water line (RMWL) and/or regional groundwater line (RGWL).

The $\delta \mathrm{D}$ and $\delta^{18} \mathrm{O}$ contents of the deep groundwater samples in this study vary from -68.5 to $-58.5 \%$ and from -8.78 to $-8.36 \%$, respectively. These data were plotted in the $\delta \mathrm{D}-\delta^{18} \mathrm{O}$ diagram together with the RMWL, RGWL (shallow) and the weighted mean of regional river water (RRW) obtained by Tan et al. ${ }^{21}$ (Fig. 7). As can be seen from Fig. 7, stable isotopic contents of the groundwater in this study are consistent with those of the shallow groundwater (RGWL) and the surface river water (RRW), but they have relative lower $\delta \mathrm{D}$ or higher $\delta^{18} \mathrm{O}$ than the RMWL.

The similarity between the regional shallow groundwater, the regional river water and the groundwater samples from the deep sandstone aquifer suggests that groundwater in the deep sandstone aquifer is recharged from precipitation rather than sealed up water during sedimentation. Moreover, it is noticed that the eight groundwater samples have limited variation of stable isotopic contents, imply that the sandstone aquifer is independent relative to the loose layer aquifer and the underlying limestone aquifer, which is similar to the previous studies that the sandstone aquifer is relatively closed and hard to be recharged by other aquifers ${ }^{3}$. Therefore, the groundwater in the deep sandstone aquifer is considered to be recharged by paleo-precipitation water and during the long time of water-rock interaction in the aquifer, $\delta^{18} \mathrm{O}$ contents of the groundwater is enriched by the wall rocks with higher $\delta^{18} \mathrm{O}$ contents or, the $\delta^{18} \mathrm{O}$ contents of the paleo-recharging water was previously enriched by the soils during penetration from surface to the sandstone aquifer. 


\section{Conclusions}

- The groundwater samples in this study can be subdivided into two types: $\mathrm{Na}-\mathrm{HCO}_{3}$ and $\mathrm{Na}-\mathrm{SO}_{4}$. And only $\mathrm{Ca}^{2+}, \mathrm{Mg}^{2+}$ and $\mathrm{Cl}^{-}$concentrations can meet the demand of WHO drinking standards.

- The correlations between major ions suggest that dissolution of evaporate and weathering of silicate minerals dominant in the sandstone aquifer, to a lesser extent, cation exchange between $\mathrm{Na}^{+}$and $\mathrm{Ca}^{2+}$ or $\mathrm{Mg}^{2+}$.

- The variation of $\delta \mathrm{D}$ and $\delta^{18} \mathrm{O}$ contents of the deep groundwater samples is limited and, they are consistent with the shallow groundwater, suggesting that the sandstone aquifer in Qianyingzi coal mine is independent relative to other aquifers and, it was recharged by paleo-precipitation and, modified by water rock interaction in the aquifer or the processes during penetration from surface to the aquifer.

\section{ACKNOWLEDGEMENTS}

This work was financially supported by National Natural Science Foundation of China (No. 41173106 and 41302274) and Natural Science Foundation of Anhui Province (No. 1308085QE77) and the Key Project of Natural Science of the Department of Education, Anhui Province, China (No. KJ2013A246).

\section{REFERENCES}

1. A.G.S. Reddy, K.N. Kumar, D.S. Rao and S.S. Rao, Environ. Monit Assess., 148, 463 (2009).

2. Y.Y. Zhao and Y.S. Pei, Procedia Environ. Sci., 13, 1739 (2012)
3. H. Gui and L. Chen, Hydrogeochemistric Evolution and Discrimination of Groundwater in Mining District, Geological Publishing House, Beijing (2007).

4. A.K. Singh, G.C. Mondal, S. Kumar, T.B. Singh, B.K. Tewary and A. Sinha, Environ. Geol., 54, 745 (2008).

5. S.K. Kuma, V. Rammohan, J.D. Sahayam and M. Jeevanandam, Environ. Monit. Assess., 159, 341 (2009).

6. R. Nagarajan, N. Rajmohan, U. Mahendran and S. Senthamilkumar, Environ. Monit. Assess., 171, 289 (2010).

7. H.R. Gui, L.H. Sun, L.W. Chen and S. Chen, Mining Sci. Technol., 21, 477 (2011).

8. L.H. Sun and H.R. Gui, J. Coal Sci. Eng., 18, 385 (2012).

9. S. Bouri, H. Abida and H. Khanfir, J. Environ. Geol., 53, 1421 (2008).

10. R. Trabelsi, M. Zaïri, H. Smida and H.B. Dhia, Geoscience, 337, 515 (2005).

11. L.H. Sun, H.R. Gui and S. Chen, J. Rare Earths, 29, 185 (2011).

12. H.R. Gui and L.H. Sun, Asian J. Chem., 25, 5941 (2013).

13. L.W. Chen, H.R. Gui and X.X. Yin, Environ. Monit. Assess., 179, 487 (2011).

14. C.L. Hu, Hydrogeol. Eng. Geology, 25, 36 (1998).

15. World Health Organization (WHO) Guidelines for Drinking Water Quality, WHO, Geneva (2004).

16. R.M. Garrels and F T. Mackenzie, Evolution of Sedimentary Rocks, Norton, New York (1971).

17. J. Gaillardet, B. Dupré, P. Louvat and C.J. Allègre, Chem. Geol., 159, 3 (1999).

18. W. McLean and J. Jankowski; eds. O. Sililo, Groundwater Quality and Sustainability in an Alluvial Aquifer, Australia, Proceedings of the XXX IAH Congress on Groundwater (2000).

19. M. Meybeck, Am. J. Sci., 287, 401 (1987).

20. H. Craig, Science, 133, 1702 (1961).

21. Z.C. Tan, B.H. Lu, J. Wang and Y.Y. Sun, J. Hohai Uni. (Nat. Sci.), 37, 650 (2009). 